Отрох Наталія Володимирівна, кандидат історичних наук, Національний педагогічний університет імені Михайла Драгоманова

\title{
ТУРЕЦЬКІ ШОВКОВІ ТКАНИНИ В УКРАЇНСЬКІЙ ХУДОЖНІЙ І РЕЛІГІЙНІЙ КУЛЬТУРІ XVII-XVIII СТ.
}

У статті розглянуто типи та особливості османських тканин, сфери їх застосування та орнаментальні мотиви. Автор дійшов висновку, щуо культура османів була вкрай сприйнятливою і відкритою для впливів і поширення на інші країни. Окреслені иляхи, якими потрапляв турецький шовк на територію сучасної України. Досліджено специфіку використання та роль турецького шовку в украӥнській художній і релігійній культурі XVII-XVIII cmст.

Ключові слова: шовк, орнамент, саз, чинтамані, чатма, камка, оксамит, зербаф, атлас.

В статье рассмотрены типь и особенности османских тканей, сферы их применения и орнаментальные мотивы. Автор пришел к выводу, что культура османов была достаточно открытой и восприимчивой для влияния и распространения на другие страны. Обозначены пути, по которым попадал турецкий шолк на территорию современной Украины. Исследована специффика использования и роль турецького шелка в украинской художественной и религиозной культуре XVII-XVIII вв.

Ключевые слова: шелк, орнамент, саз, чинтамани, чатма, камка, бархат, зербаф, атлас.

The article discusses the types and characteristics of Ottoman cloth scope and ornamental motifs. An author came to the conclusion, that a culture of Turkish was extremely receptive and open for influences and distribution on other countries. Outlined ways the Turkish guy-sutures got that on territory of modern Ukraine. Investigated the use and the specific role of silk in Turkish Ukrainian art and religious culture XVIIXVIII centuries.

Key words: silk, ornament, saz, Chintamani, chatma, damask, velvet, zerbaf, satin.

Вплив османського костюма, включаючи тканини та орнаменти, поширився далеко за межі Оттоманської Порти. Персонажів, одягнених в османські тканини, можна побачити на флорентійських і венеційських картинах епохи Ренесансу. Елементи османського костюма міцно утвердилися в культурі балканських народів, а також в культурі Болгарії, Польщі та Румунії.

Український одяг XVII-XVIII стст. - як світський так і духовний - важко уявити без турецьких впливів. Турецькі тканини використовували заможні українці, козаки здобували одяг як військові трофеї, козацька старшина отримувала подарунки від татарської та турецької верхівки. Починаючи з др. пол. XV ст., багато літургійних та 
євхаристичних виробів, у тому числі й облачення православної церкви, створювалися в османських майстернях.

Мета даної статті - розкрити специфіку та роль турецького шовку в українській художній і релігійній культурі XVII-XVIII стст.

Серед останніх досліджень турецького шовкового текстилю можна виділити колективну працю «Мистецтво османського шовківництва», видану турецькими дослідниками. У книзі розглядається історія турецького шовку з 1288 по 1918 рр., подано цінний ілюстративний матеріал [10].

Осередками вивчення турецького шовку османського періоду стали музейні установи, у фондах яких зберігаються означені зразки. Наприклад, Текстильний музей у Вашингтоні, округ Колумбія, придбав шовкові турецькі наволочки (тип тканини чатма) на подушки, покривала, як і музеї декоративного або прикладного мистецтва в Парижі, Кельні, Відні та Гамбурзі.

Викладач Університету Вірджинії Аманда Філіпс присвятила низку наукових розвідок османському оксамиту [12].

Османська імперія, що простягалася на три континенти, являла собою культурний простір, в якому змішувалися, здавалося б, несумісні художні традиції: Китаю, Персії, Індії, арабського Сходу і християнського Заходу. Виробництво тканин в Османській імперії з погляду техніки, матеріалів, якості виконання й орнаментації досягло високого рівня в XVI ст. Імперія пройшла кілька важливих етапів у своєму культурному розвитку від заснування і до періоду кін. XVIII - поч. XIX стст., коли почав переважати вплив Європи. 3 одного боку, в османську культуру очевидний внесок анатолійських сельджуків, з іншого боку, Османська імперія, розташовуючись на торговому шляху, який пов' язував Схід і Захід, активно вбирала в себе інші культурні традиції. Після захоплення Константинополя, османи, що заволоділи столицею Візантійської імперії, потрапили у візантійське культурне середовище й одночасно засвоювали традиції індійського й іранського мистецтва. Цей вплив був настільки великим, що досі дослідникам дуже складно розрізнити ранні турецькі й іранські тканини.

Місто Бурса було першою столицею Османської держави (1326-1365) і важливим перевалочним пунктом на євразійському торговельному шляху, що дозволяло османам бути посередниками у торгівлі шовком-сирцем. Через ці території проходили кокони або незабарвлені шовкові нитки, вироблені в північних провінціях Ірану Сефевідів; коли європейські купці (в основному італійські) купували шовк, турки стягували податок. Зниження експорту іранського шовку-сирцю в сер. XVI ст. у зв'язку з політичною боротьбою спровокувало початок внутрішнього шовківництва в Османській імперії.

Починаючи з XVI ст. відзначається бурхливе зростання текстильного виробництва. Його основними центрами стали Бурса і Стамбул, де крім лляних, виробляли і шовкові тканини. У районі Бурси вдалося акліматизувати шовкового хробака. Указами султана суворо регламентувалося виробництво сировини і тканини (вага пряжі, тканини і ціни на них) [11].

Більшу частину виробництва становили однотонні шовкові тканини, виконані в техніці блискучого атласу з малюнком. Такі матерії вважалися свого роду символом Османської імперії. Існували три різновиди подібних тканин: чатма, оксамит (кадіфе), 
серасер, камка (кемха). Перелічені тканини випускалися в різних районах, i в кожному з них культивувалися особливі техніки виконання й оригінальні малюнки, а також побутували місцеві традиції, пов'язані із носінням шовку. У XV й на поч. XVI стст. найрозкішнішою шовковою тканиною визнавали оксамит, пізніше його місце зайняла камка, а в др. пол. XVI ст. 3'явилася дорогоцінна парча, яка витіснила камку. Шовковий оксамит (кадіфе) монохромний оксамит з однаковим рівнем ворсу, який виготовлявся в XIV-XV стст. в Бурсі, а з XVII ст. - в Стамбулі, користувався особливим попитом у Свропі. Найбільш цінний і поширений вид османського оксамиту називався «чатма»-рельєфний різновид, який поєднував гладку поверхню фону й ворсову структуру візерунка $з$ локальним включенням золотих і срібних ниток. Відмінність оксамиту «чатма» від простого оксамиту полягала в тому, що мотиви на «чатма» були рельєфними, «піднятими» над основою. Серед оксамиту «чатма» найкращою вважалася тканина з подвійною основою, виткана золотою або срібною ниткою, а також поєднання металевих і шовкових ниток [6].

Виробництво шовку мало величезне значення для Османської імперії, і тому для організації державного виробництва шовку та збору податків були докладені великі зусилля, а за контроль над прибутками від торгівлі шовком велися часті війни [11].

Шовк займав особливе місце в османських церемоніях і громадському побуті як показник високого соціального становища. Шовковими тканинами деякі вищі державні чиновники отримували частину своєї платні. Шовк з давніх часів асоціювався з розкішшю й багатством. Навіть рай у Корані описується як місце з шовковими подушками і килимами. У масовій свідомості шовк був настільки пов' язаний з пожадливістю і розкішшю, що ранній іслам навіть забороняв чоловікам носити шовковий одяг. Формально дотримуючись цієї заборони, чоловіки одягали шовкове плаття не на голе тіло, а поверх бавовняного або лляного нижнього одягу [6].

З текстилю, що використовувався для оббивки меблів робили також наволочки на подушки для сидіння в приймальнях у палацових павільйонах і будинках знаті, а також для інтер'єрів наметів під час військових кампаній [11, с. 6].

Шовкові ковдри виготовлялися в Османській імперії з XVI до поч. XIX стст. Спочатку шовк зшивався з тонкою лляною тканиною, пізніше гаптований вишитий шовк кріпився на грубій бавовняній тканині. Такі ковдри використовувалися для накривання ліжка, іноді заміняли штори [9, с. 220].

Ще одним напрямом текстильного виробництва Османської імперії було виготовлення килимів. Килими для східної культури -це не тільки напрямок мистецтва, а й невід’ємна частина життя як заможних людей, так і простолюду. Килими в Османській імперії використовувалися скрізь: для молитов у мечетях, для прикрашання стін, розстеляли на підлозі, на килимі спали, приймали гостей тощо.

Оригінальність справжнього килима в тому, що його не тчуть на верстаті, а в'яжуть власноруч: до натягнутих ниток основи руками прив' язують короткі шматки вовняної або шовкової нитки, відмінність плетіння полягає у тому, яким типом вузла скористується майстер. Турецький вузол, т. зв. герді, відрізняється від перського (сеіех) тим, то в ньому короткі вовняні або шовкові нитки переплітаються з двома сусідніми нитками основи, тоді як в перському вузлі ці нитки переплітаються лише з однією з двох.

Традиції килимарства були привнесені в Османську імперію туркменами, які мігрували в Анатолію з Центральної Азії. Як правило, розрізняють два типи 
анатолійських килимів: з геометричними малюнками й емблемами, що беруть початок, безперечно, від традицій тюркських кочівників; килими, малюнок на яких запозичений 3 інших джерел, наприклад, 3 архітектурної декорації i, пізніше, з книжкового оформлення. Серед останніх, орієнтовані на продаж килими з візерунками, зірками, малюнками і фігурами, званими «пташиними». Більшість килимів зіткані в червоних, синіх, темно-синіх, коричневих, жовтих і білих барвах.

Геометричні прикраси використовували у всіх аспектах повсякденного життя турків від архітектури до ремесел. На килимах геометричні прикраси домінували за принципом нескінченності зайнятого переплетення форм у композиції.

На турецьких килимах здебільшого зустрічаються квардрати, ромби і зигзаги, характерні також для мистецтва Кавказу, Ірану тощо. Геометричний орнамент у турецькому мистецтві переважав до ХІІІ ст. Подальші зміни, як не дивно, були пов'язані 3 широким поширенням ідей суфізму серед різних верств мусульманського суспільства. Геометричні прикраси відбивають єдність філософії існування аскетико-містичного періоду суфізму, що набув поширення в Анатолії після Ібн Арабі, а вегетативні прикраси в орнаментах почали вживатись під впливом філософії Мевлана Джалал ад-Дін Румі (вираження почуттів через символи природи) [2].

Образні прикраси є найбільш цікавими елементами сельджукського мистецтва, вони демонструють як повсякденне життя (наприклад, розваги, полювання), так і $є$ включеннями до орнаментів із символічним значенням. Людські фігури, живописання левів, ведмедів, кроликів, гірських козлів, павичів, коней і міфічних істот були представлені на камені, штукатурці, плитці, тканині. Надприродні істоти, такі як сирени, гарпії, грифи, дракони і двоголові орли, символізували захист, владу, багатство, родючість, світло, удачу; всесвіт, планети і сузір'я зодіаку використовувалися в якості образних прикрас, які поєднувалися з шаманськими символами Центральної Азії та іранськими художніми мотивами.

У оздоблені килимів переважали геометричні орнаменти, винятки становили килими, які ткали на замовлення заможних турків, на них геометричні моделі замінювалися фігурами тварин, які були образним відображення прикрас періоду. По периметру килимів розміщували візерунки з куфічного письма.

Орнаментальні мотиви турецьких шовкових тканин справили значний вплив на європейську стилістику.

Так, ще під час правління Сулеймана I були розроблені стилізовані квіткові візерунки, знакові для класичного стилю Османської імперії.

Найпопулярнішими першовзірцями орнаментів були варіації квіткових мотивів, що характеризуються хвилястими вертикальними стеблами з квітучими пальметами, гвоздиками, тонкими півоніями або гранатами. Гратчастий візерунок, створений переплетінням стебел квітів, став популярним за часів правління Сулеймана I i активно використовувався в архітектурному декорі плитки з міста Ізнік [11].

Орнамент 3 «живою» решіткою, яка чергується з великими квітковими голівками, пов'язаний 3 т. зв. «Коронкою Стефана», прекрасно ілюструє обмін ідеями і декоративними мотивами між Сходом і Заходом у результаті створення тканин османськими ткачами на експорт, орієнтованих на модні тенденції тогочасної Свропи [9, с. 180-181]. 
Т. зв. стиль саз, який був популярним у Туреччині протягом XVI-XVII стст., вплинув i на текстильний дизайн. Він реалізовувався у хвилеподібному викладені мотивів і нерівних краях на листі й квітах. Цей стиль пов'язаний з творчістю придворного живописця Шах Кулі, який емігрував з Ірану і служив при дворі Сулеймана I. Кара Мемі, улюблений учень і наступник Шах Кулі, додав до репертуару стилю квіткові мотиви, в тому числі гвоздики, троянди, тюльпани, гіацинти і вишні. Вони залишалися улюбленими мотивами всього «тюльпанового періоду» Ахмеда III (1703-1730).

На шовкових тканинах зустрічаються також різні квітучі дерева з довгими гілками, частіше кипариси; в стилі таких композицій помітний китайський вплив, а саме такі сюжети як чинтамані (три перлини, з'єднаних у формі трикутника) i «губи Будди» (дві хвилеподібні лінії) [5, с. 87].

Чинтамані у перекладі з санскриту значить «сприятливий камінь», мотив виник у буддійській образності, зокрема у такому стилі виконано картини в печерах Центральної Азії. Елементи дизайну з чинтамані називають «тигровими смугами» і «леопардовими плямами». Іноді чинтамані поєднується з квітковими елементами в тонкому балансі двох відмінних стилів, хвилясті лінії і кругові елементи розділяються квітами, щоб створити особливі мотиви. У будь-якому поєднанні елементи чинтамані покликані захистити власника і збагатити його духовно [10].

Наприкінці XVII - на поч. XVIII стст. османське мистецтво відчуває деякий вплив перського, а потім європейського мистецтва. Перебування посольства Мехмед-ефенді в Парижі сприяло виникненню у Франції моди, що отримала назву «алятюрка» (потурецьки, на турецький лад), яка реалізувалася у декоративному мистецтві, архітектурі та одягу.

Шовк, придбаний європейськими купцями, часто використовувався для оздоблення палаців або церков по всій Свропі, пошиття як світського, так і сакрального одягу, його носили високопоставлені чиновники, у нього загортали церковні реліквії. Слід сказати, що й угорці, і поляки теж відчували турецький вплив, оскільки їм доводилося воювати з турками або спілкуватися з ними. І не тільки вони сприйняли елементи оттоманського костюма, але й вся Європа.

Турецьку «моду» українці засвоювали як за посередництва Польщі, особливо реєстрове козацтво, так і безпосередньо через турків і татар. Шовкові й бавовняні тканини на територію України в основному завозили зі Сходу: з Китаю, Індії, Персії, Туреччини, Закавказзя, Середньої Азії, а також з Криму. На торгових площах великих міст можна було придбати різноманітні привізні матеріали для одягу - оксамит, парчу, прошву, стрічки, шнури тощо. Імпортні речі коштували дуже дорого, тому незаможні громадяни використовували їх лише для святкових очіпків або запасок, прикрашали ними верхній одяг або деякі елементи орнаменту, творчо переробляли на вишивку або набійку. Люди більш заможні використовували шовкові тканини (тафту, камку, оксамит, атлас, алтабас тощо) і для пошиття буденного одягу.

Із турецьких матерій були поширеними алтабаси, в яких металеві нитки превалювали, надаючи тканині вигляд кованого металевого листа. Відомі також смугасті алтабаси із золотими смугами по кольоровому грунту і різнобарвними «травками» в золотих смугах. Утім, цінувалися алтабаси саме за ефектність металевої поверхні. 
До вельми коштовних золотих тканин східного походження (привозилася з Персії й Туреччини) належав також «зербаф» (або «изорбаф» з рос.) (від перс. «зербафт» («зер»золото і«бафт» - тканина, від бафтен - ткати), - шовкова парчева тканина, заткана суцільно тонкими золотими й срібними нитками (обвитими золотою або срібною біттюплющеним дротом), зі складними узорами шовковими, срібними і золотими.

3 другої декади XVIII ст. у Росії зербафи вже відомі під назвою «парча» (з перс. partsche - зербаф, а також шматок, або з тат. parca - парча, узор), що проникає тоді ж до українського лексикону, уживаючись паралельно з традиційною назвою «злотоглав» [4, с. 148-149].

Турецький оксамит зазвичай був різних відтінків червоного кольору зкрупними золотими, срібними або різнобарвними шовковими витканими узорами, що складалися з рослинних елементів, майже завжди об'єднаних у геометричні фігури. Східні оксамити використовувалися головним чином на оббивку святкового кінського убору старшини: подушок, крилець, чапраків, тебеньок, повстей, а також на верхній одяг.

Завдяки тугості та зносостійкості, камка використовувалася старшиною на пошиття святкового й службового верхнього одягу (жупанів і кунтушів), підпанцирних стьобаних каптанів, іноді йшла на підбій до коштовних кунтушів.

Турецькі атласи були переважно чисто шовкові, дуже цупкі й гладкі, одноколірні, однак зустрічалися також узорчаті різнобарвні й коштовні золоті. Останні в більшості випадків мали в забарвленні малиновий колір у поєднанні з блакитним і зеленим, а також пряденим золотом і сріблом.

Атлас мав широку сферу застосування. Його використовували на пошиття й оздоблення (на «лиштви», підпушку) святкового і вихідного верхнього одягу (каптанів, жупанів, кунтушів), на підбій і підпушку до представницьких дорогих опанчей і «вілчур», виготовлення святкових поясів; заможна старшина також шила з атласу святкові шаровари [4, с. 160].

Залежно від місця виробництва усім узористим матеріям були притаманні певні схеми оформлення забарвлення й орнаментації.

Для турецьких тканин характерні різкі контрасти в декорі і крупний, дещо важкий, візерунок. Улюбленими елементами орнаменту були дещо стилізовані тюльпани, плоди шипшини, гвоздика й плоди граната, зазвичай об'єднані у геометричні фігури, найчастіше зіркоподібної форми або у вигляді кіл, овалів, замкнених в клейма пальмет. У XVIII ст. узор тканин стає дрібнішим. Однак гама кольорів турецьких тканин була обмежена і одноманітна: домінують відтінки червоного кольору в поєднанні із золотом та зеленими або блакитними деталями [1, с. 368].

Шовкові тканини турецького походження увійшли в широкий вжиток і козаків. Д. Яворницький писав: «Розбивши татар чи турків, пограбувавши панів чи євреїв, козаки повертаючись на Січ, привозили з собою безліч грошей, одягу й дорогих тканин. Відомості, що дійшли до нашого часу свідчать, що саме з одягу здобували собі запорізькі козаки на війні - шуби, жупани, шаровари, сорочки, смушкові шкури тощо» [8, c. 157$]$.

Нема сумніву, що крій запорізького одягу, особливо високих шапок, широких шароварів, довгих жупанів і широких поясів, східного походження і запозичений ними 


\section{ТУРЕЦЬКІ ШОВКОВІ ТКАНИНИ В УКРАЇНСЬКІЙ ХУДОЖНІЙ I \\ РЕЛІГІЙНІЙ КУЛЬТУРІ ХVII-ХVIII СТ.}

в татар і турків. Це запозинення здійснювалося або захопленням під час наїздів, або купівлею, шляхом дарування з боку вищих татарських і турецьких властей запорізьким козакам [8, с. 163].

«Польські письменники XVIII ст. відзначали, що запорізькі козаки носили широкі шаровари з золотим галуном замість опушки, суконні з відкидним рукавом полукунтуші, білі шовкові жупани, шовкові з золотими китицями пояси й високі шапки зі смушковими околишем сірого кольору і червоним шовковим вершком, який закінчувався китицею. За описами інших очевидців, одяг запорожців складався з жупана, зробленого із сукна різних кольорів, шовкового каптана також різних кольорів, яскравої черкески (схожа 3 жупаном), шароварів, шовкового кушака, шапки-кабардинки з видри і кошлатої вовняної бурки-вільчури. На ноги взувалися сап'янові чоботи» [3, с. 47, 50].

Широкі пояси з матерії були обов'язковою деталлю костюма вищого козацтва України, як і польського панства в XVII-XVIII стст. Найпоширенішими серед запорожців були турецькі й перські пояси, які привозили вірменські купці. Пояси носили обов'язково: ходити без пояса вважалося непристойним. Окрім опояски на сорочці носили широкі пояси (кушаки) на верхньому одязі. У небагатих людей пояси були тафтяні; у багатих вони робилися з дорогих матерій та прикрашалися цінностями. Пояси були смугасті, (наприклад білі з коричневими і вишневими смугами почергово або блакитні, коричневі і вишневі смуги з золотом), і в кожній смузі розташовувалися своєрідні візерунки. За східними взірцями на Україні засновували у XVIII ст. мануфактури, що виготовляли золототкані шовкові, т. зв. кунтушеві пояси [7, с. 68].

До наших часів зберіглося дуже мало східних тканин XVI-XVII стст. Лише те, що з запорозьких куренів і «мальованих скринь» старшини перейшло до церков, зберіглося по ризницях, хоча у зіпсутому вигляді, оскільки було переробленим на речі культового вжитку.

Отже, культура османів була вкрай сприйнятливою і відкритою для впливів і поширення на інші країни. Османська орнаментика легко впізнається, як і костюм тюрків. На території України широко використовували тканини турецького походження для виготовлення одягу, сакральних речей, оздоблення інтер'єрів і готові шовкові речі, які здобувалися козаками в якості трофеїв, або отримувалися як подарунки. Кольори таких тканин були різноманітними, але переважав червоний із багатьма відтінками. Навіть духовні особи носили ряси червоних кольорів. Найпопулярнішими шовковими матеріями були ті, що ткалися разом із золотом і сріблом із зображенням візерунків і фігур.

\section{Jimepamypa:}

1. Левинсон-Нечаева М. Одежда и ткани XVI-XVII векав / Левинсон-Нечаева М. // Государственная Оружейная палата Московского Кремля: сб. науч. трудов. - Москва, 1954. - С. 307-384. 2. Матеріали Музею турецьккого й османського мистецтвва в м. Стамбул. Туреччина. 3. Ніколаєва Т. О. Історія українського костюма / Ніколаєва Т. О. Київ : Либідь, 1996. - 176 с. 4. Славутич С. Шовкові тканини в костюмах військової еліти і урядовиів Української козацької держави та їхня тогочасна місиева термінологія / Славутич С. // Історико-географічні дослідження в Украӥні : зб. наук. праць - 2007. Вип. 10. - С. 143-180. 5. Стайнова М. Тенденции в културнато и идейното развитие в 


\section{ТУРЕЦЬКІ ШОВКОВІ ТКАНИНИ В УКРАЇНСБКІЙ ХУДОЖНІЙ І \\ РЕЛІГІЙНІЙ КУЛЬТУРІ ХVII-ХVIII СТ.}

османското общество през двадесете години на ХVIII в. (1718-1730) / М. Стайнова. Studia Balcanica. - № 13.- 1977. - C. 72-94. 6. Эртюрк Н. Искусство костюма эпохи Османской империи XVI-XVIII вв. [Електронний ресурс] / Н. Эртюрк : диссертаџия ... кандидата искусствоведения : 17.00.04. - Москва, 2005. - 143 с.- Режии доступу: http:// www.dslib.net/muzee-vedenie/iskusstvo-kostjuma-jepohi-osmanskoj-imperii-xvi-xviii-vv.html. Дата доступу: 21.11.2015. - [Без суичільної пагінації]. 7. Школьна О. Шовк у побуті украӥнців XVII-XIX століть і питання його музейного експонування / Школьна О. // Питання історії, науки і техніки. - 2014.-№ 3. - С. 61-73. 8. Яворницький Д. I. Історія запорізьких козаків / Яворницький Д. I. ; пер. з рос. I. І. Сварника. -Львів : Світ, 1990. - 319 c. 9. Erber Christian A Wealth of silk and velvet: Ottoman fabrics and embroideries/Christian Erber. Bremen : Edition Temmen, 1992. - 288 p. 10. Ipek: Osmanli dokuma sanat? / Atasoy Nurhan, Walter B. Denny, Louise W. Mackie, Hulya Tezcan. - Londra : Azimuth Editions Limited, 2001.Say-s - 360. 11. Nazanin Hedayat Munroe Silks from Ottoman Turkey / Department of Islamic Art, The Metropolitan Museum of Art. -Url: http://www.metmuseum.org/toah/hd/tott/hd_tott.htm. 12. Phillips Amanda The historiography of Ottoman velvets, 2011-1572: scholars, craftsmen, consumers / Amanda Phillips // Journal of Art Historiography. - № 6. - 2012. - P. 1-26. 